\title{
Os diversos métodos para se chegar ao 'eu': análise filosófica do conto Um discurso sobre o método de Sérgio Sant'anna
}

\author{
The various methods to come to the 'self': philosophical analysis of the \\ tale a discourse On the method Sérgio Sant'anna's
}

Rafael César Pitt ${ }^{1}$

1 Professor na Universidade Federal do Amapá, Brasil.

E-mail: rafaelpittunifap@gmail.com . Orcid: http://orcid.org/0000-0003-4045-6574

RESUMO: O presente artigo apresenta uma análise filosófica do conto Um discurso sobre o método escrito por Sérgio Sant'Anna. O objetivo da análise é demonstrar que o conto é construído como um esforço de mímesis da filosofia cartesiana. Parte-se do pressuposto que o texto artístico comporta múltiplas interpretações, principalmente quando construído em diálogo com a filosofia. Do tema em destaque, o cartesianismo defende a ideia de que a subjetividade (o 'eu') é um dado radical sem ligação com o entorno material, social e cultural. Todavia, o contista contemporâneo discorda deste isolamento e constrói uma narrativa na qual o 'eu' é descoberto através de vários métodos. Com isto amplia-se a compreensão hodierna de que o sujeito não está fechado sobre parâmetros científicos estritos, e sim se abre a inúmeras manifestações fenomênicas. Esta análise literária e filosófica vai amparada nos conceitos analíticos de Gerard Genette em $O$ discurso da narrativa, assim como em concepções literárias de Edgar Allan Poe, Júlio Cortázar e Ricardo Piglia além, é claro, de algumas obras de René Descartes. O resultado alcançado é um exercício especulativo que, à primeira vista, parece uma crítica ao puro cartesianismo, mas que, ao contrário, se posiciona como um complemento que reconhece e amplia os caminhos da modernidade para o estudo do 'eu'. Em acréscimo indicam-se semelhanças entre o conto e a obra de Descartes, o que reforça nossa tese de mímesis e complementariedade entre a obra literária e a filosófica.

Palavras-chave: Eu; Literatura; Filosofia.

ABSTRACT: This article presents a philosophical analysis of the tale A discourse on the method written by Sérgio Sant'Anna. The purpose of the analysis is to demonstrate that the tale is constructed as an work of mimesis of the cartesian philosophy. It is assumed that the artistic text has multiple interpretations, especially when built in dialogue with philosophy. Of the main theme, cartesianism defends the idea that subjectivity (the 'self') is a radical datum without connection with the material, social and cultural environment. However, the contemporary storyteller disagrees with this isolation and constructs a narrative in which the 'self' is discovered through various methods. In this way, the current understanding is extended that the subject is not closed on strict scientific parameters, but opens itself to innumerable phenomenal manifestations. This literary and philosophical analysis is supported by Gerard Genette's analytical concepts in Narrative Discourse, as well as in the literary conceptions of Edgar Allan Poe, Júlio Cortazar and Ricardo Piglia, as well as, of course, some works by René Descartes. The result is a speculative exercise which, at first glance, seems a criticism of pure cartesianism, but on the contrary, it stands as a complement that recognizes and expands the ways of modernity for the study of the 'self'. In addition there are similarities between the tale and the work of Descartes, which reinforces our thesis of mimesis and complementarity between the literary and the philosophical work.

Keywords: Self; Literature; Philosophy. 


\section{Introdução}

Este artigo irá analisar o texto Um discurso sobre o método (1989) do contista carioca Sérgio Sant'Anna (1941 -). O conto apresenta algumas características interessantes como a capacidade de retratar a vida urbana e o senso comum com acidez e ironia mordazes. O contista também produziu textos em outros gêneros como poesia, romance e teatro e chegou, em mais de um momento, a ganhar prêmios em reconhecimento por sua obra.

O conto em específico que o presente analisa traz a história de um jovem faxineiro predial que, numa pausa do trabalho, sobe até a marquise externa da sala em que estava para fumar um cigarro. Confundido com um suicida em potencial pelas pessoas que passavam na rua, o jovem se sente atraído pela situação incomum que ajudou a criar e, enquanto pensa em uma série de situações de sua própria vida, permanece parado. Neste ínterim, o corpo policial e de bombeiros chega ao prédio, aborda o rapaz, o tira dali e o encaminha para uma casa de reclusão para doentes mentais.

De certa forma o conto é uma construção padrão deste formato literário. Seu número de páginas, 20, garante aquela unidade de efeito da qual Edgar Allan Poe (2009, p. 114) tanto frisou. Este detalhe externo à história é acompanhado de outro interno, a saber, a tensão e a intensidade mantidas pelo narrador onisciente. Munido de variados tipos de focalização, este recurso narrativo é largamente utilizado com destaque à sua ironia e mordacidade, com a capacidade de narrar sobre os fatos mais sórdidos como se fossem os mais triviais. Esta narração que assusta por sua simplicidade diante do incomum desarma o leitor mediano e o prepara para o nocaute ao final, como bem metaforizou Júlio Cortázar (1974, p. 151).

O final, como já antecipado, remete o leitor a um turbilhão psíquico de revolta, surpresa e até mesmo humor (!). Terá lido corretamente? É uma pergunta comum a se fazer após a última linha. O motivo é que no momento em que o faxineiro é considerado demente, e esta tarja de louco é posta sobre ele, não há qualquer resistência contra ela. O próprio limpador de janelas a aceita. Todos a aceitam! Isto faz com que de dentro da história de superfície submerja a bistória secreta do conto, como teorizou Ricardo Piglia (2004, p. 90), arrebatando o leitor para além de sua posição inicial de leitura.

Esta loucura que é identificada e normatizada pelos códigos sociais envoltos na cena da prisão do faxineiro é, antes de um sinal de demência, de consciência porque o dito personagem, cuja biografia é a de um multe excluído (social, econômica e moralmente), vem a perceber pela primeira vez em sua vida, um 'eu' (!), um lampejo de subjetividade livre, pensante e capaz de ações próprias.

Eis o núcleo da história secreta do conto: o indivíduo urbano contemporâneo vive de tal forma mergulhado em sua luta pela sobrevivência que tem sua subjetividade, seu 'eu', solapado pelas condições materiais, principalmente para aqueles excluídos economicamente. Sendo assim, temos uma mudança de perspectiva sobre o pensamento cartesiano e a postulação da subjetividade como natureza pensante independente do corpo e do mundo externo.

Seguindo este entendimento problematiza-se: qual ou quais possíveis relações existem entre este conto e o filósofo francês do século XVII René Descartes? O nome do conto é evidente indicação de que o conteúdo da narração pretende dižer algo sobre Descartes. Será contra sua obra? Será contra o racionalismo como um todo? Como entender o que o conto quis manifestar enquanto literatura mais de 300 anos depois da filosofia receber à luz $O$ discurso do método?

Antecipam-se aqui algumas conclusões a fim de estabelecer com mais clareza a hipótese que se seguirá. A história secreta do conto é uma alternativa ao projeto cartesiano de construir uma ciência inequívoca sobre o 'eu'. Não há um ponto firme e sólido no qual podemos alicerçar nosso saber. O que há é uma 
pluralidade de perspectivas que flutuam sobre o mesmo objeto. Não há uma 'alma racional' ou uma 'mente pensante’ diferente do corpo e mais fácil de ser conhecido do que a matéria. Ao contrário, a subjetividade pode surgir ou desaparecer dependendo das condições materiais. O 'corpo' físico reduzível às suas dimensões matemáticas e controláveis é uma ilusão, pois o homem vive lançado no tecido social e é produto de forças estranhas.

Apesar deste diálogo sobre corpo e mente já ter recebido e ainda continuar a receber novas interpretações e versões - de fato aqui não se nega a riqueza do tema dualista - a hipótese que ora se apresenta cai para outro lado. Privilegiar-se-á a linguagem em detrimento da epistemologia ao buscar em Aristóteles o conceito que norteará a análise. Trata-se da mímesis na Arte Poética.

A epopeia, o poema trágico, bem como a comédia, o ditirambo e, em sua maior parte, a arte do flauteiro e a do citaredo, todas vêm a ser, de modo geral, imitações. Diferem entre si em três pontos: imitam ou por meios diferentes, ou objetos diferentes, ou de maneira diferente e não a mesma (ARISTÓTELES, 2005, p. 19).

Esta passagem da obra é tida até nossos dias como uma das definições mais fundadoras dos gêneros artísticos hegemônicos no Ocidente. Ela separa e categoriza a narração, a poesia e o drama a partir de suas configurações 'arquetípicas' ao molde grego. Desta maneira, quando Aristóteles diz que a imitação é feita por 'meios diferentes' se refere a ritmo, discurso e harmonia; por 'objetos diferentes' fala dos caracteres nobres ou vulgares e por 'maneira' quer dizer se por discurso direto ou indireto, todas ao mesmo tempo ou em ação.

A intenção que se segue não considera a distinção aristotélica tout court. Não haverá uma análise da mímesis no conto seja tomando em qualquer de suas significações. O que se terá é uma apropriação parcial do conceito, especificamente naquilo que permite operacionalizar a hipótese proposta. Ei-la: Sérgio Sant'Anna mimetiza René Descartes em dois níveis. O primeiro nível é o do 'meio', isto é, qual ou quais métodos são capazes de apresentar a mente de uma pessoa? Só há um caminho para demonstrar a alma humana? O 'eu' exige apenas 01 método ou aceita vários? O segundo nível é o do 'objeto', ou seja, de quem falamos quando falamos da mente humana? Do sujeito puro cartesiano claro e evidente como um número ou do sujeito real urbano transformado pela sociedade em apenas mais um número?

A escolha desta forma parcial de se apropriar do conceito do estagirita se justifica na medida em que o objeto analisado exige uma liberdade teórica dilatada. Estamos falando de um texto artístico que joga com regras próprias com o pensamento moderno e que não presta contas a uma tradição restrita de interpretação filosófica. Com as ferramentas literárias que dispõe o texto artístico estabelece um diálogo não linear com o cartesianismo e com Descartes, sem incorrer nos puritanismos teórico-conceituais, mormente exigidos a analistas profissionais.

Nosso objetivo não será esgotar as nuances conceituais da mímesis nem definir o conto como um conceito. Aceitamos sem reservas a definição de obra aberta de Umberto Eco e o postulado de que a arte contemporânea não comporta definições estéticas e filosóficas fechadas, mas apenas um modo de ser de acordo com seus próprios pressupostos.

Isto posto apresenta-se a divisão da análise. Depois da Introdução seguirá uma rápida rememoração do que foi o método para o filósofo francês; seguida de uma parte mais longa onde não apenas o conto é apresentado como também os distintos métodos aplicados pelo narrador para indicar os processos internos da mente do personagem principal. Esta parte dará conta do primeiro nível de nossa hipótese. O segundo nível será trabalhado no tópico seguinte - os sujeitos antagônicos entre si - quando serão confrontados os 
diferentes 'objetos’ da imitação. Por fim breves conclusões são traçadas. Boa leitura!

\section{0 método para Descartes}

Há duas coisas igualmente notáveis no projeto cartesiano: de um lado, sua ambição e grandiosidade e, de outro, a modéstia que Descartes emprega para formulá-lo. Neste sentido, a famosa primeira frase de seu livro de 1637, o Discurso do Método, pode ser lida assim: "o bom senso é a coisa mais bem distribuída do mundo" (1985a, p. 31) - e completada por nós desta maneira: 'desde que o bom senso seja condurido pelo método que criei.

Há no cerne da vida deste filósofo a crença profunda acerca da insuficiência metodológica da ciência de seu tempo. Qualitativamente aplicada e sem um eixo unificador, a ciência acumulava dúvidas e incertezas ao restringir a aplicação da matemática e favorecer a pluralidade de opiniões contraditórias sem base comum. A proposta cartesiana será então oferecer um método que possa ser aplicado indistintamente a todos os ramos científicos de modo a garantir a unidade do saber, ou seja, com ele, a unidade da ciência será garantida pela unidade do método que, por sua vez, será o resultado da unidade de um intelecto: o dele.

De maneira bem objetiva e sem margem de interpretação a segunda parte do Discurso do método (1985a) traz as quatro regras do método. A primeira é "clareza e distinção": só é aceito na ciência aquilo que o espírito concebe sem qualquer dúvida; a segunda é "análise": diante de dificuldades no conhecimento devese dividi-las em quantas partes forem necessárias para solucioná-las; a terceira é “ordem”: deve-se ordenar os pensamentos dos mais simples aos mais complexos e estabelecer ordem entre eles quando não se apresentarem naturalmente ordenados; a quarta é "enumeração": deve-se proceder a revisões e enumerações completas para ter certeza de que todos os elementos foram considerados.

O método cartesiano ambiciona atingir uma representação intelectual abstraindo todas as condições materiais e psicológicas que podem afetar o pensamento. A verdade é algo a ser procurada no interior da própria mente, o que não quer dizer que a verdade seja subjetiva e sim que ela possui a subjetividade como lugar e fundamento da verdade.

O 'eu' ou subjetividade é a um dos conceitos mais investigados na modernidade filosófica. Suas transformações foram várias e acompanharam as distintas fases do pensamento moderno. Desde a coisa pensante para Descartes, indo para a mente capaz do conhecimento adequado com Espinosa, passando pela apercepção transcendental que distingue a unidade da identidade da consciência em Kant, e chegando à intuição pura que se autocria segundo Fichte. Em todas estas fases - entre outras aqui omitidas - o 'eu' ou subjetividade consolidou a interioridade do pensar como uma das contribuições mais originais do pensamento europeu e moderno.

Descartes é um filósofo racionalista e isto determina o ponto de vista a partir do qual ele pensa a natureza da subjetividade. Segundo Johannes (HESSEN, 1976, p. 19-23) esta dimensão interior do homem é o lócus onde o objeto externo à mente grava a imagem do conhecimento. Ou seja, o 'eu' está do lado oposto do corpo, da matéria, do mundo externo. Põe-se com isso uma das características mais fortes deste filósofo que é o dualismo corpo-mente, ou sujeito-objeto.

René Descartes considera que a dimensão interior do homem possui primazia sobre a externa. Isto não significa superioridade qualitativa de uma sobre a outra e sim prioridade ontológica, ou seja, o movimento do conhecimento começa com o 'eu' e somente em segundo instante passa pelo objeto exterior. Daí sua filosofia marcada pelo problema da representação do objeto na mente humana. Nas palavras de Franklin (SILVA, 1993, p. 9) "à hegemonia do sujeito corresponde o que se convencionou denominar em Descartes 
de primado da representação".

Esta tese filosófica da subjetividade pensante como prior do saber passa por várias dimensões do pensamento cartesiano que fogem ao escopo da presente análise. Por exemplo, poder-se-ia falar de forma adequada da existência dos corpos externos e das condições de sua representação; ou do conceito de Deus como garantia de verdade das representações, além é óbvio da descoberta do cogito como intuição inicial de qualquer representação. Porém, restringir-se-á à questão do método e de suas principais características.

Logo, Descartes lança mão de um método capaz de organizar o real ao decodificar em termos matemáticos o elemento extenso do ser. Agindo assim, o pensador garante as condições de universalidade e necessidade à sua filosofia ao dar à representação uma linguagem clara e distinta. Existe em seu modus operandi a crença de que os caracteres matemáticos são universais e necessários para quem quer que seja. Amparado nesta crença, Descartes defende no Discurso do Método que a divergência das opiniões dos homens se deve mais à falta de um método do que à diferença de bom senso ou talento entre eles. "Pois não é suficiente ter o espírito bom; o mais importante é aplicá-lo bem” (DESCARTES, 1985a, p. 31).

A utilidade do método cresce na proporção das empresas humanas. Na filosofia, por exemplo, sendo ela obra dos grandes mestres e espíritos do passado, acredita Descartes que seria natural encontrar solidez e segurança em seus conhecimentos. Porém, quão grande é a decepção do filósofo quando constata “[...] que, nem por isso, nela se encontre algo sobre o qual não se dispute e, por conseguinte, nada que não seja duvidoso" (DESCARTES, 1985a, p. 36).

Todavia, enquanto a filosofia se mostra como terreno incerto, as matemáticas alegram o filósofo “[...] por causa da certeza e da evidência de suas razões" (DESCARTES, 1985a, p. 36). Ou seja, as vantagens que o filósofo admira e deseja copiar para seu método são a inteligibilidade e a instrumentalidade. Seu objetivo será garantir a clareza e a evidência de todas as representações mentais, ou seja, de todos os processos cognitivos do 'eu' pensante.

Desde a primeira de suas Regras para a Direção do Espírito Descartes está convencido de que “[...] todas as ciências estão de tal modo conexas entre si que é muitíssimo mais fácil aprendê-las todas ao mesmo tempo do que separar uma só que seja das outras" (DESCARTES, 1985b, p. 13). Por conta disto seu método se torna um dos grandes sucessos epistemológicos da modernidade abrindo caminho para uma longa série de discussões e incursões na alma humana.

Para o que nos serve aqui basta notar que: 1) o método é único, linear e impessoal. O motivo é patente: Descartes trata da mente humana de maneira impessoal, como se a mente fosse um objeto cognoscível, movimento este na filosofia chamado de metafísico; 2) o método é racional, ou seja, opera com premissas lógicas e almeja um fim igualmente compreensível. O método é uma ferramenta da consciência e em nenhum momento perde este posto. A linguagem matemática do método não deixa dúvidas sobre suas propriedades. O método é um procedimento de ordem e medida, posição e arranjo, simplicidade e composição, distinção e relação, interrupção e continuidade, simultaneidade e sucessividade, facilidade e dificuldade $^{1}$.

É contra este modelo de acesso à mente humana que o conto de Sérgio Sant'Anna irá se posicionar concordando com a importância do método, mas ampliando para versões distintas do molde matemático-analítico cartesiano. Abaixo segue uma apresentação do conto ao mesmo tempo em que se busca apresentar a variedade de métodos aplicados pelo narrador para o estudo do 'eu', cumprindo aquele primeiro nível da mímesis que alertamos na Introdução.

${ }^{1}$ Estes sete pares de signos matemáticos foram retirados ao longo dos capítulos das Regras para a Direção do Espírito. 


\section{Os métodos para Sérgio Sant'Anna}

Nesta parte do artigo analisar-se-á o conto em tela com fundamentos estruturalistas de Gerard Genette e $O$ discurso da narrativa (1979). Primeiro há uma apresentação do personagem principal, em seguida da cena que sustenta a fábula e depois a análise de quatro métodos aplicados para se estudar o 'eu' do personagem.

O personagem principal do conto é um sujeito simples e sem sofisticação. Exigiria como condição para desfrutar do prazer de fumar metade de um cigarro que tinha no bolso tão somente uma pausa do trabalho de limpar as vidraças externas do $18^{\circ}$ andar. Este prazer seria potencializado assumindo a posição contemplativa ao sentar na beirada da marquise e balançar as pernas sobre a cidade. "Ele não queria dispersar este prazer misturando-o com o trabalho." (SANT'ANNA, 1989, p. 87).

A aurea mediocritas deste personagem anônimo de 25 anos não conceberia em condições normais que um ajuntamento de pessoas pudesse se interessar por ele. Isto é, que ele, uma persona tão comum, pudesse despertar algum interesse por quem quer que fosse. "Não estava habituado a ser este centro e olhou para baixo e para cima e até para trás, a janela às suas costas. Talvez pudesse haver um princípio de incêndio ou algum andaime em perigo ou alguém prestes a pular." (SANT'ANNA, 1989, p. 87) Como não encontrou nada de anormal por fim concebeu a surpreendente ideia de ser ele ali, sentado na marquise, o centro das atenções.

Este pacato cidadão era senhor de uma modéstia tão natural que faria sua face ruborizar diante do menor elogio, como ensinou Sêneca ${ }^{2}$. A situação em que se encontrava sendo identificado com um potencial suicida era completamente inesperada e não planejada. "E digamos que a pouca importância que dava a si próprio não permitia que aflorasse seriamente em seu campo de decisões a possibilidade de um gesto tão grandiloquente" (SANT'ANNA, 1989, p. 87). E, pela forma como vinha carregando as dores de sua vida até então, poder-se-ia dizer que seu instinto cego de sobrevivência era pelo menos 40\% mais forte que seu instinto de morte. Este rapaz era tão resiliente que em época de desvalorização da moeda nacional aproveitava o descaso que as pessoas faziam para caminhar de cabeça baixa e colher na rua aquelas moedas de pouco valor que os transeuntes não se dignificavam a abaixar para pegar.

Naquele dia o prazer de fumar a metade do cigarro vinha escorado pela xícara de café com três quartos de açúcar que havia tomado antes de pegar no serviço. Este prazer era tão mais caro quanto lhe custara passagem de volta para casa de trem após o expediente. Ou seja, entre voltar para casa com fome depois da meia noite ou sentir uma (01) sensação de prazer doce antes do batente às quatro da tarde, o faxineiro escolhera o café que teria, como reforço hedonista, o sabor do tabaco de meio cigarro que trazia no bolso.

Além deste cálculo utilitarista pelo seu maior prazer, o jovem também calculara o preço do desconforto a ser pago por não voltar para casa. Teria que mais uma vez dormir na rua pelo menos por mais uns dois dias até o pagamento sair e ter dinheiro para a passagem de trem. Até lá havia de vagar pela cidade da hora que acordasse em algum banco ou gramado da cidade até o início do turno do serviço. Como já tinha feito isto muitas vezes, seu hábito mais eficiente "procurando distrair-se olhando o mar e os aviões na ponta do Aterro, perto do aeroporto, ou frangos giratórios nos fornos envidraçados ou, nos cartazes de cinema, mulheres nuas e homens de ação" (SANT'ANNA, 1989, p. 88).

O preço pode parecer alto para alguns, mas para este personagem, o doce do café e o gosto do

2 SÊNECA. Cartas a Lucílio. 5 ed. Lisboa: Caloust Gulbenkian, 2009. (Carta 11: Sobre o rubor da modéstia). 
cigarro the pareceram muito mais valorosos e concretos do que situações costumeiras a serem vividas no futuro imediato. Cálculo muito bem feito para "um homem que vivia nas imediações do presente, pois o passado não lhe trazia nenhuma recordação agradável, em especial, e o futuro era melhor não prevê-lo, de tão previsível." (SANT'ANNA, 1989, p. 89).

Este limpador de janelas senhor do mais duro estoicismo, do mais pobre cálculo utilitarista e do mais insosso dos hedonismos era muito vulnerável simbolicamente. O nome Panamericana que trazia gravado em seu peito lhe cobria de respeitosa aura. Uma aura nebulosa, indefinida, relacionada à importante competição internacional que o Brasil participava. Esta aura lhe cobria de legalidade ao levar aquela palavra importante gravada em seu uniforme para bancos e gramados quando dormia ao relento. Ela lhe colocava imediatamente acima dos mendigos e outros párias da sociedade, embora possuíssem em comum os bolsos vazios e o respeito incompreendido pelas pessoas notáveis transformadas em estátuas de praças públicas.

Eis, então, nosso personagem principal. É um jovem muito pobre acostumado com árduas condições materiais. Desescolarizado, subempregado, rebaixado aos piores trabalhos e situações sociais. Raso, sem espaço para a vaidade ou um pouco de individualidade, totalmente preso às condições de sobrevivência na cidade grande. Pai de uma família numerosa e suburbana, exposto a riscos de morte no serviço, apagado como pessoa e ser livre. É este sujeito massacrado pela vida contemporânea que o autor do conto irá usar como matéria prima para aplicar diversos métodos e descobrir nele uma 'subjetividade', um 'eu'.

Para isto o autor põe este personagem em uma situação limite! Como dito antes, o faxineiro está na marquise no $18^{\circ}$ andar e é confundido pelas pessoas na calçada como um potencial suicida. Na verdade ele estava lá somente para fumar um toco de cigarro, e quando se levanta para voltar ao trabalho, a multidão reage com uma vaia contra ele. A turba se percebe lograda em sua expectativa! Não havia ali nenhum suicida - que garantiria um show macabro ao se jogar da marquise e mudar a rotina muda de todos que vissem o salto e o sangue -, e sim apenas um faxineiro "enrolando" antes de pegar no batente. Esta vaia da multidão perturbou o rapaz, de certa forma o ofendeu e provocou nele a reação de mostrar para aquelas pessoas que a vaia era injusta. Ele sente aquela vaia como um desafio, como um chamado para mostrar quem ele é, do quê ele é capaz de fazer. Tanto que o faxineiro, ao invés de se retirar da marquise, prefere dar um passo adiante - bem para a beira da marquise, aos centímetros antes da morte certa - só para ouvir das pessoas lá embaixo o som do aplauso e da aprovação nos gritos de "pula", "pula".

Esta cena de embate entre o ajuntamento de pessoas anônimas torcendo pelo pior e o jovem limpador de janelas posto em posição de ataque contra elas será a cena tensionadora do conto. A apresentação do personagem principal que veio antes desta cena serviu apenas para compô-la, e o que vier depois será uma consequência da situação dramática ali representada. Isto porque o narrador onisciente do conto irá suspender a narração da história e irá construir pequenas digressões sobre o que se passa dentro do rapaz. Cada uma destas pequenas digressões será um método diferente escolhido pelo narrador para mostrar como a subjetividade do sujeito, ou seja, o ‘eu do faxineiro' surgiu a partir daquela situação limite imposta a ele.

O primeiro método é o que chamaremos de político. Basicamente ele expõe uma maneira pela qual o personagem principal poderia exercer poder sobre as outras pessoas. Como nosso personagem principal não ocupa qualquer cargo político, obviamente não dispõe de legitimidade, restando-lhe apenas o uso da força para coibir os demais. O narrador onisciente com focalização interna descreve este fenômeno subjetivo do faxineiro nas seguintes palavras. "Aquele pessoal lá embaixo, como ele próprio, a mulher e os filhos, não era gente bonita, bem alimentada e imbuída de elevados propósitos; pelo contrário, era preciso aplacá-los com sangue e circo.” (SANT'ANNA, 1989, p. 92-3).

Mesmo sem refletir conscientemente sobre este poder político que lhe aflorava internamente, o 
personagem apresenta um 'eu' motivado por intenções políticas por duas razões bem sensíveis. A primeira é que "o caso dele era premente: a situação financeira de carência absoluta, agravada pelo fato de ter se destacado tanto nos últimos instantes na Panamericana, de forma incompatível com a política de pessoal da Companhia." (SANT'ANNA, 1989, p. 93). E a segunda é que "havia o fato principal de que ele tinha uma só vida para viver, apesar de, paradoxalmente, andar ventilando, nesses últimos momentos, como um exercício, a hipótese de livrar-se dela." (SANT'ANNA, 1989, p. 93).

Ou seja, tanto pela primeira razão quanto pela segunda o personagem está experimentando - reforço: ainda que sem consciência plena disto - "métodos violentos de transformação da sociedade" (SANT”ANNA, 1989, p. 93). Isto porque a situação tensionadora na qual ele se encontra, desafiado por um grupo de pessoas desconhecidas a se matar sem qualquer motivo concreto o faz perceber que "a sociedade como um todo era uma abstração” (SANT’ANNA, 1989, p. 93). E de fato se não fosse pelo acidente de ser confundido com um suicida em potencial, nosso herói continuaria se identificando ingenuamente com a massa. Porém, graças ao método político aplicado pelo narrador, podemos dizer que "ele estava se tornando agora, sempre vertiginosamente, um individualista” (SANT'ANNA, 1989, p. 93).

O segundo método é o que chamaremos de estético. De acordo com este caminho o faxineiro experimentaria fruições estéticas de profunda beleza. Aqui a universalidade do belo garante ao rapaz a eficácia da experiência. Isto é um ponto muito interessante a se observar. A Beleza não é um conceito movido pelo intelecto, como bem explicou Kant, e sim pelo livre jogo da sensibilidade com a razão. Sendo assim, o Belo é e está acessível à humanidade de uma forma muito mais democrática do que qualquer conceito, pois abdica de erudição ou capacitação prévia. Para experimentar a beleza basta estar diante dela. E nosso personagem, ali na marquise, próximo do entardecer, com uma vista favorecida ao mar, aos aviões, aos prédios e ruas, enfim, à cidade, está em excelente localização para desfrutar do Belo.

Aproximava-se a hora do crepúsculo, uma hora bonita, ele também achava. Para realçar tal beleza na melancolia, havia a possibilidade desta tornar-se também a hora do seu crepúsculo, que ele podia fazer belo e significativo. Se pulasse, transformar-se-ia numa personagem de jornal, um mártir da crise econômica, merecendo mais do que um simples registro, porque teria conseguido transformar a Avenida Rio Branco lá embaixo, assim batizada por causa de um barão (que ele desconhecia), num pandemônio (SANT'ANNA, 1989, p. 93).

Movido pela melancolia de estar à beira de morrer em um final de tarde, podendo contemplar o crepúsculo e identificar nesta coincidência o fim de sua própria vida, nosso herói "se avizinhava de um ideal romântico que é o de morrer jovem e no auge da fama. Só não era belo” (SANT’ANNA, 1989, p. 94). Aqui, mais uma vez, o narrador onisciente não poupa sua mordacidade ao mostrar metodicamente como este sujeito tão nulo de qualidades pode ter sua subjetividade desnuda pela narração. "Aos argumentos de praxe de que tudo isso de nada lhe serviria depois de morto, ele poderia contrapropor — se além de romântico fosse poeta ou filósofo - que estava gozando com a máxima intensidade os lances dramáticos que podiam anteceder a morte, como num duelo ao entardecer”. (SANT’ANNA, 1989, p. 94).

Desta maneira podemos entender que o método estético revela o 'eu' do faxineiro ao identificar nele uma base emotiva-racional que desfruta de sensações e deleites artísticos diante da contemplação da cena e da situação. "A cidade era inquestionavelmente bela, com seus picos e montanhas, o oceano, algumas aves marinhas, (...) o que, quando nada, demonstrava que não é preciso estar a par de certas definições e correntes estéticas para usufruir dos efeitos e dos materiais que as compõem," (SANT’ANNA, 1989, p. 94).

O terceiro método é o que chamaremos de existencialista. O existencialismo é posto na narrativa 
justamente pela sensação de desorientação e confusão que se encontra o rapaz na marquise. A possibilidade concreta da morte alimentada pela torcida assassina das pessoas na calçada criou no plano subjetivo do rapaza a "consciência largada no mundo, que podia morrer a qualquer instante e não era feliz (...) como alguma personagem de Jean-Paul Sartre, além de ter sido acometido, há pouco, de uma boa dose de náusea existencial em relação a si próprio e à massa humana." (SANT’ANNA, 1989, p. 94).

O quarto e último método é o que chamaremos de psicanalítico. De acordo com este método o narrador apresenta a subjetividade do personagem a partir dos impulsos inconscientes que o mesmo demonstra em sua cena na marquise. Há definitivamente o impulso da violência contra si mesmo, ou seja, aquela carga nervosa e tanática mal canalizada que o põe como um suicida em potencial. " $\mathrm{O}$ fato de sua força voltar-se contra ele próprio, num momento em que não podia dirigi-la para fora, era somente a parte mais óbvia da questão" (SANT'ANNA, 1989, p. 95).

Havia também seu narcisismo, seu desejo de ser considerado belo e insubstituível. O fato de estar ali à vista de uma pequena multidão mexeu com seu 'eu narcísico’ que então aflorou, e a cada instante daquela tensão entre ele e a plateia era também um instante de gozo narcísico. O narrador mordaz é implacável com nosso herói neste trecho.

Quanto ao narcisismo, refletido no ato de pavonear-se no espelho da massa, ele poderia canalizá-lo para atividades socialmente mais ajustadas, como progredir no seu ramo de vidraças e assoalhos, até deixálos tão impecavelmente limpos que the devolvessem uma imagem sem distorções e fantasias perniciosas. (SANT'ANNA, 1989, p. 95)

E havia também o impulso da avidez pela fama, pela glória, pelo espetáculo que aquela tarde comum de faxina predial tinha se tornado. Era inegável que o rapaz estava prolongando aquela cena até o máximo de sua tensão. Ele podia ter se recolhido e retornado ao trabalho há muitos instantes atrás, mas o fato de provocar a plateia dando um passo à frente, de seguir imóvel com os olhos a chegada dos carros da polícia e dos bombeiros, além da óbvia paralisação das atividades de todos os funcionários da empresa Panamericana - tudo isto - compunha aquele show cuja estrela solitária era nosso showman oprimido na marquise.

Havia ainda no método psicanalítico a dimensão mais profunda da subjetividade em tela. Se na primeira parte do método psicanalítico o 'eu' do personagem foi avaliado sob o prisma dos impulsos recalcados, na segunda dimensão deste mesmo método o paradigma será o arquétipo da origem mítica do ser.

Diz-nos o narrador que o personagem nasceu de uma mãe muito pobre que vinha de trem elétrico para o centro da cidade pedir esmola com o filho no colo debaixo das marquises da cidade. E que o fato de hoje, naquele dia tão singular da vida do jovem, o mesmo ter gasto seu dinheiro com o café era o signo inconsciente para evitar o trem elétrico que o levaria de volta para casa. A consequência desejada seria a obrigação de subir na marquise para fumar o cigarro, criando a aparente superação do trauma infantil de ser usado pela matriarca para sensibilizar os pedestres da cidade. Enfim, estas ações concretas e contrárias entre si (andar de e evitar o trem - abaixo ou acima da marquise) - seriam, portanto, os signos inconscientes que apontariam para o desejo arquetípico mais profundo de sua psique. Cito o texto:

o fato de ele ter escolhido (ou ter sido escolhido por ela, pouco importa, pois não existem coincidências, mas causalidades necessárias) uma profissão que o levaria sempre para bem próximo das marquises e que agora estivesse na iminência de jogar-se de uma delas para cair dentro do berço, que era a calçada. A fortificar tal dedução, havia o fato indiscutível de que ele trilhara literalmente esta via na vida, onde era sempre obrigado a pegar um trem elétrico para chegar ao local de trabalho que se confundia com o mítico ponto onde seria acalentado e daí, talvez, se pudesse explicar-lhe seu delírio ambulatório e até 
curá-lo dele, (SANT’ANNA, 1989, p. 96-7).

Encerra-se aqui esta parte da análise que mostra os diferentes 'meios' pelos quais o contista mimetiza o filósofo e apresenta diversos métodos para abordar o 'eu'. Nossa conclusão provisória é que há mais de uma abordagem eficiente para indicar a natureza e as ações da subjetividade focalizada.

Agora percorremos o segundo nível da mímesis na qual o contista mimetiza a obra do filósofo apontado diferentes 'objetos', ou seja, sujeitos bem distintos entre si. Para isto contamos com a comparação entre o personagem principal da história e o 'eu enunciado’ por Descartes. Como sabemos, o francês escreveu sua obra em primeira pessoa e se colocou como objeto de seu discurso, isto é, sempre reforçou a tese de que suas ideias se aplicavam a ele. Se isto era um efeito retórico ou apenas uma forma de expressão é questão que aqui deixaremos intacta. O que nos caberá é comparar este personagem-consciência posto como referência do discurso.

\section{Os sujeitos antagônicos entre si}

Descartes começa assim sua meditação:

Há já algum tempo eu me apercebi de que, desde meus primeiros anos, recebera muitas falsas opiniões como verdadeiras, e de que aquilo que depois eu fundei em princípios tão mal assegurados não podia ser senão mui duvidoso e incerto; de modo que me era necessário tentar seriamente, uma vez em minha vida, desfazer-me de todas as opiniões a que até então dera crédito, e começar tudo novamente desde os fundamentos, se quisesse estabelecer algo de firme e de constante nas ciências. (DESCARTES, 1988, p. 2, grifo meu).

Debaixo do subtítulo 'Das coisas que podemos colocar em dúvida' o filósofo francês escreve este parágrafo no qual nos diz que considera imprescindível, em algum momento de sua vida, por em dúvida os saberes que tinha sobre todas as coisas a fim de tentar encontrar algo de verdadeiro apesar de tudo e de todos. Ora, em nosso conto, graças ao narrador heterodiegético com focalização onisciente, conseguimos experimentar esta decisão também em nosso personagem principal. Claro que não com a mesma consciência, nem com a mesma autoafirmação lúcida, mas misturada a uma série de sensações e lampejos psíquicos confusos.

De fato nosso personagem foi posto na mesma posição que o filósofo, porém de forma independente de sua vontade. Desde que percebeu as pessoas lá em baixo "não lhe passou pela cabeça que pudesse ser ele o centro das atenções" (SANT'ANNA, 1989, p. 87), "e digamos que a pouca importância que dava a si próprio não permitia que aflorasse seriamente em seu campo de decisões a possibilidade de um gesto tão grandiloquente" (SANT'ANNA, 1989, p. 87). Todavia, uma vez ali, nosso herói teve uma série de assuntos desconexos disparados em sua cabeça. Teria que passar as próximas duas noites na rua porque gastara o dinheiro da passagem com o café. Decisão acertada considerando a sensação boa de doce em sua boca e ao hábito consolidado de dormir nos bancos das praças. Hábito mal visto pela política da empresa que proibia trânsito dos funcionários uniformizados em locais de moral suspeita como bares e ruas mal frequentadas. Lugares que por outro lado o livravam do convívio enfadonho da família esfomeada.

Todas estas coisas passaram como um raio pela sua cabeça quando as pessoas foram atraídas por ele, e embora ele não tivesse a menor ideia/vontade de se jogar, o fato de perceber o poder que exercia sobre aquelas pessoas despertou nele uma sensação nova, uma sensação de liberdade que está subjacente àquela decisão livre do filósofo de avaliar seu próprio saber. Nosso personagem também se sentiu livre para pensar sobre o que estava acontecendo e qual seu papel naquilo. 
Não que ele se dispusesse a ceder àqueles apelos, bem entendido; apenas descobria, um tanto perplexo e até fascinado, que esta era uma alternativa plausível para um ser humano como ele, em dificuldades, mas de posse de todos os seus movimentos. E isso lhe concedia uma liberdade insuspeitada e uma leveza, uma vez que um fio muito tênue podia separá-lo da meta comum à espécie, que é não sofrer. (SANT'ANNA, 1989, pg. 90)

Descartes e o faxineiro da Panamericana - Serviços Gerais estão no mesmo ponto de suas vidas. Vão seriamente pelo menos uma vez tentar entender o que os rodeia. O filósofo segue a jornada:

Agora, pois, que meu espírito está livre de todos os cuidados, e que consegui um repouso assegurado numa pacífica solidão, aplicar-me-ei seriamente e com liberdade em destruir em geral todas as minhas antigas opiniões. Ora, não será necessário, para alcançar esse desígnio, provar que todas elas são falsas, (...) mas, visto que a ruína dos alicerces carrega necessariamente consigo todo o resto do edifício, dedicar-me-ei inicialmente aos princípios sobre os quais todas as minhas antigas opiniões estavam apoiadas. (DESCARTES, 1988, p. 2, grifo meu).

Há aqui uma fina ironia que une/separa nossos dois sujeitos. Descartes gostava de morar sozinho e dispunha de soldo suficiente para manter um ou dois criados fixos. Dava-se ao luxo de manter hábitos extravagantes como dormir até o meio dia e de detestar arrumar o quarto. Quando ele escreve que conseguiu repouso assegurado numa pacífica solidão está se referindo a uma casa aconchegante e afastada dos centros urbanos e da vida pública. Mesmo que modesto para os padrões contemporâneos, o filósofo pode ser considerado um bon vivant estudioso do século XVII. E ambicioso também, pois se ocupou por longos anos a construir o edifício do saber cientifico.

Quão distante e oposto está nosso rapaz de 25 anos morador da periferia carioca. Seu repouso assegurado em pacífica solidão é uma estreita marquise do $18^{\circ}$ andar de um edifício comercial em obras. Desajustado social e economicamente, tanto na vida quanto nesta marquise "é preciso não esquecer que ele estava habituado a ocupar posições delicadas no espaço” (SANT'ANNA, 1989, p. 90). Quem em sã consciência e autonomia financeira escolheria subir em tal lugar perigoso para relaxar? O edifício aqui não é uma metáfora para o conjunto dos saberes; evidente que não, e sim uma construção em reforma que abrigará uma firma de engenharia. É um local desagradável, com homens fazendo barulho transitando de um ponto a outro com martelos, pregos, madeiras e todo tipo de ferramentaria pesada. Não há aconchego algum, nenhum tapete ou canto macio. Não há sequer equipamento de segurança para nosso jovem lavar vidraças externas e, no entanto, ali, sobre a marquise e de costas para a janela, ele está sozinho, em paz, relaxado com seu cigarro e seus lábios ainda doces pelo café.

Mutatis mutandis ambos estão em locais e condições agradabilíssimos para exercer a função do pensamento e da reflexão.

Descartes prossegue em sua meditação e aborda a incerteza contida no conhecimento sensível. "Tudo o que recebi, até presentemente, como o mais verdadeiro e seguro, aprendi-o dos sentidos ou pelos sentidos: ora, experimentei algumas vezes que esses sentidos eram enganosos, e é de prudência nunca se fiar inteiramente em quem já nos enganou uma vez" (DESCARTES, 1988, p. 3). Ou seja, podemos confiar nos nossos sentidos, mas com restrições. E não é esta a experiência narrada quando nosso rapaz percebe o ajuntamento de pessoas na calçada olhando e apontando na direção dele? Sim, nosso funcionário não concebe de imediato que ele seja o motivo de atração da atenção. Tanto que ele procura ao seu redor outra coisa que fosse mais digna do fato e, nada encontrando, conclui por exclusão que ele seja a foco.

Ora, neste ponto o narrador procura desviar nosso entendimento dizendo que "talvez pudesse haver 
um princípio de incêndio ou algum andaime em perigo ou alguém prestes a pular" (SANT'ANNA, 1989, p. 87), mas sua intenção é inserir sub-repticiamente a reação pastelão do personagem que "olhou para baixo e para cima e até para trás” (SANT'ANNA, 1989, p. 87) e que só chegou à conclusão depois de realizar ‘operações bastante lógicas' em sua mente. Não é exagero dizer que, ao lado oposto do filósofo cartesiano que pondera racionalmente sobre o que seus sentidos lhe mostram, o narrador revela um personagem que pensa letargicamente.

Outro ponto no qual podemos apontar os antagonismos entre os dois 'objetos' aqui discutidos é a relação que ambos mantêm com o fundamento último da realidade. Ambos os sujeitos experimentam a crença em Deus de formas totalmente diferentes, a saber, o filósofo é otimista e racionalista, o faxineiro é pessimista e rancoroso.

Descartes oferece o conceito de Deus como garantia da verdade das representações do 'eu'. Consciente de que a validade das representações é marcada pela temporalidade da intuição, o filósofo busca oferecer um suporte metafísico que perdure para além do momento da representação. Para cumprir tal tarefa ele apresenta três provas da existência de Deus: a primeira é a prova pelo efeito, a segunda é pela existência e a terceira é pelo conceito. Sem a evidência da existência de Deus todas as intuições do 'eu' podem ser resultado das artimanhas do gênio maligno. E também a ciência como cadeia de proposições não é possível porque seus elos podem desfazer-se logo após serem elaboradas.

A respeito da primeira prova o filósofo afirma que algumas ideias são mais perfeitas que outras devido à diferença entre aquilo que representam. Algumas representam acidentes e contingências enquanto outras seres e substâncias. Estas últimas "contêm em si (por assim falar) mais realidade objetiva, isto é, participam, por representação, num maior número de graus de ser ou de perfeição do que aquelas que representam apenas modos ou acidentes" (DESCARTES, 1988, p. 35).

Dentre as ideias mais perfeitas, isto é, que participam por representação do máximo de ser possível, temos a ideia de Deus. Ao mesmo tempo, Descartes reconhece que é incomensurável a diferença de perfeição do 'eu' finito para o ser infinito. Como então o finito possui a ideia de infinito? A resposta viável para o pensador é admitir a evidência de que Deus pôs no finito sua ideia (DESCARTES, p. 1988, p. 39). Trata-se da prova pelo efeito: observando o efeito da existência da ideia de Deus no 'eu' sou levado a crer que existe a causa desta ideia. Considerando que cada ideia é causada por um ser proporcional ao que representa, sou levado a crer que a ideia de infinito é causada por um ser igualmente infinito.

A segunda prova é semelhante à primeira no sentido de avaliar o a posteriori, porém, em vez de julgar a causa da ideia de infinito Descartes amplia sua perspectiva e questiona sobre a causa de sua existência. Terá ele sua origem derivada da ação de seus pais? Se assim foi, quem terá sido causa da existência de seus pais? Este raciocínio logo conduz o princípio de causalidade a um círculo vicioso. Somente um ser que causa a si próprio (causa sui) pode interromper o fluxo do princípio de causalidade. Como criador Ele imprimiu em sua criatura a marca de sua criação que é, justamente, a ideia de Deus.

No que se refere à terceira prova, o famoso argumento ontológico, Descartes diz que em um ser soberano projetam-se todas as perfeições conhecidas (DESCARTES, 1988, p. 58). Ora, a existência é uma perfeição e, um ser que não existe, não pode ser soberano. Está claro que esta prova pelo conceito é polêmica e suscita vários questionamentos ${ }^{3}$. Por ora o fundamental se restringe ao seguinte: para Descartes, assim

\footnotetext{
3 Um livro interessante para quem deseja discutir o assunto mais aprofundadamente. OLIVEIRA, Manfredo; ALMEIDA, Custódio (orgs.). O Deus dos filósofos modernos. 2. ed. Petrópolis, Editora Vozes, 2003, 1 vol., 246 p. De uma forma ou outra, os grandes marcos no debate sobre o citado argumento são Anselmo, Descartes e Kant. Há basta bibliografia sobre o assunto.
} 
como quando penso num ângulo reto não é preciso recorrer à experiência para comprovar a existência deste ângulo, igualmente Deus, a partir do momento que o concebo como dotado de existência, abdica de uma comprovação empírica devido à clareza e evidência que minha mente passa a conceber sua ideia.

A ideia de Deus torna-se a garantia de verdade de todas as ações do 'eu'. O otimismo cartesiano deixa claro que se há alguma garantia de tudo o que sabemos e fazemos, esta depende exclusivamente Daquele que ampara o 'eu' e todo o conhecimento possível.

Bem diferente disto é a experiência do personagem faxineiro com o ser supremo. A começar por sua fé tremulante que obedecia mais ao estômago do que a razão, a religião cristã para ele ficara marcada pela condenação do suicídio - logo esta - a opção que justamente lhe afetava.

Embora por várias vezes houvesse abandonado o Cristo por ídolos de periferia como orixás e exus, já ouvira falar, este homem, durante as catequeses de infância, em sua paróquia - depois das quais era servido um lanche-, que os pobres mereceriam um lugar de destaque no reino dos céus e que, por outro lado, os suicidas não teriam perdão (SANT'ANNA, 1989, p. 101).

É claro que esta relação tão concreta com a fé não alcançaria estabilidade ou profundidade no 'eu' do jovem. Porém, ali da marquise o Cristo Redentor estava bem à vista do mesmo e, é importante lembrar, a cena já estava chegando a seu auge e a tensão entre ele e a plateia estava próxima do máximo. De uma forma desesperada e, porque não dizer, crédula

[...] o que o homem fez foi abrir os braços para o Cristo, movido um pouco por uma súplica vaga, porque ele não sabia como sair honrosamente daquela armadilha, e um pouco por exibicionismo ou espírito de imitação, que não raro são a gênese da loucura, quando um ser humano percebe que, se não podem certas realidades ser transformadas, pode-se simplesmente mudar a si mesmo, trocando-se um papel modesto por outro melhor, como o de Napoleão ou outro general, em casos extremos, ou de um simples guarda de trânsito, nos menos graves. Imitação que, naquele caso específico, fez sucesso, pois a massa vibrou lá embaixo, talvez pela popularidade do modelo, talvez por acreditar que a personagem que o encarnava finalmente iria voar (SANT'ANNA, 1989, p. 101).

Contudo o medo da morte e o antagonismo crescente não podiam ser derrotados, e só por um milagre o jovem sairia dali sem graves consequências. Talvez justamente por isso desejasse o inusitado - o milagroso - que poderia ser um movimento daquela estátua gigante que abençoava a cidade, numa clara indicação divina de que ele não deveria pular e que sua vida valia a pena. Todavia, por mais bela e mágica que fosse imaginar esta cena, o pessimismo e o rancor acumulado de anos sem ajuda dos céus logo dominaram sua mente sobre o que aconteceria de fato.

Mas nunca, desde a inauguração da estátua, em 1931 — incluindo a visita do Papa, em 1980 —, fora visto mexendo um só dos braços para apaziguar uma dessas tormentas, individuais ou coletivas, nem quando eram as águas das chuvas que, descendo do morro que sustentava a sua imagem, iam provocar a catástrofe lá embaixo, levando na enxurrada casas, animais e pessoas e induzindo estas pessoas a pensar em algum castigo que certamente teriam merecido. Não era então previsível que movesse o Cristo um dos dedos que fosse, pelo homem na marquise (SANT'ANNA, 1989, p. 100).

E por fim, para terminar esta análise da mímesis do contista aponta-se o que o 'eu' do filósofo entende por 'sonho' e o que o 'eu' do faxineiro pensa a respeito. Em outras palavras, se aquilo que tanto o filósofo francês quanto o jovem carioca veem e vivem faz parte da realidade (isto que vulgarmente chamamos mundo) ou se não passa de um sonho. 
Os motivos teóricos pelos quais Descartes apresenta seu famoso argumento do sonho não nos importam aqui. Importante é notar que ele faz do sonho o contraponto negativo de sua mente lúcida, inclusive chegando a supor os inúmeros erros que se passam nas mentes daqueles que, sonhando, julgam erradamente o mundo: os loucos.

Mas, ainda que os sentidos nos enganem às vezes, no que se refere às coisas pouco sensíveis e muito distantes, encontramos talvez muitas outras, das quais não se pode razoavelmente duvidar, embora as conhecêssemos por intermédio deles: por exemplo, que eu esteja aqui, sentado junto ao fogo, vestido com um chambre, tendo este papel entre as mãos e outras coisas desta natureza. E como poderia eu negar que estas mãos e este corpo sejam meus? A não ser, talvez, que eu me compare e esses insensatos, cujo cérebro está de tal modo perturbado e ofuscado pelos negros vapores da bile que constantemente asseguram que são reis quando são muito pobres; que estão vestidos de ouro e de púrpura quando estão inteiramente nus; ou imaginam ser cântaros ou ter um corpo de vidro. Mas quê? São loucos e eu não seria menos extravagante se me guiasse por seus exemplos. (DESCARTES, 1988, p. 5, grifo meu).

As palavras do filósofo não precisam de explicação. São claríssimas. E não poderiam ser mais discrepantes da experiência de nosso personagem limpador de janelas que, diametralmente ao pensador francês, experimenta seu próprio 'eu' como um sonho!

Vamos lembrar aqui a biografia do jovem na marquise. Paupérrimo, sem instrução, massa trabalhadora informe e anônima social e culturalmente. Este sujeito nunca teve voz própria. Nunca teve 'lugar de fala'. Nunca teve sequer 'lugar'. Empurrado para a periferia, frequentador das ruas e sarjetas, admirador secreto das máquinas giratórias de assar frango e dos pôsteres de cinema. Mudo, afônico, abaixo. Lumpesinato. O narrador usa de nada menos que escárnio para indicar tal estatuto humano e social deste sujeito.

Aos que condenam tal procedimento metafórico, é preciso relembrar que a classe trabalhadora, principalmente o seu segmento a que chamam de lúmpen, ainda está longe do dia em que poderá falar, literariamente, com a própria voz. Então se pode escrever a respeito dela tanto isso quanto aquilo. (SANT'ANNA, 1989, p. 103).

Este sujeito, quando é retirado da marquise pelo chefe dos bombeiros, balbucia esta frase: "É como se fosse um outro, compreende? - ele disse ao bombeiro, [...] - Alguém possível dentro de mim, que estivesse soprando pensamentos na minha cabeça." (SANT'ANNA, 1989, p. 103). E de fato, foi esta experiência de descoberta de si que o rapaz passou naqueles instantes tensos sobre a marquise. Sua subjetividade até então tinha sido de completa alteridade - sempre ecoando as múltiplas vozes da pobreza extrema -, mas por causa da atenção indevida da plateia sobre ele, e do poder que experimentou sobre este público "é que haviam ocorrido em sua mente alguns fenômenos bastante complexos, que modificaram a sua visão de mundo e que ele gostaria de expor, inclusive a si mesmo" (SANT'ANNA, 1989, p. 103).

Por isso sua passividade e perplexidade ao ser abraçado pelo bombeiro e retirado para o interior da sala, fora da marquise. Contudo, os códigos sociais que regeram toda sua vida ainda permaneciam intactos. Ele continuava sendo aquele trabalhador obsoleto e sem fisionomia de antes, com a diferença que agora tinha sido o responsável por uma grande confusão num dia de trabalho da empresa Panamericana - Serviços Gerais. Toda a mudança que acabara de acontecer tinha se passado exclusivamente em sua subjetividade, em seu interior ver a si, em seu 'eu' recôndito.

Porém o treinamento do bombeiro não chegara a considerar certos aspectos mais recônditos, sutis e contraditórios da mente e, como um profissional objetivo dentro das limitações dos seus deveres, não 
teve dúvida em seu veredicto. — É louco — avisou lá para dentro, ao mesmo tempo que empurrava o homem para o interior da sala, onde foi imobilizado. (SANT'ANNA, 1989, p. 103).

A situação é tão mais estarrecedora quanto o narrador nos surpreende com a fácil aceitação deste novo 'rótulo' pelo rapaz. O faxineiro não repudiou esta nova 'identidade'. Mas por que ele teria docilmente assimilado a tarja de 'louco' e ido de bom grado terminar a história do conto num hospício acompanhado de enfermeiros? Explica-nos a própria narração. O rapaz percebera que a "Panamericana tinha sido até então para ele não apenas um emprego, uma firma na qual trabalhava, mas um invólucro, materializado pelo uniforme, dentro do qual se enfiava - ele que se sentira, desde o berço, como uma espécie de coisa oca" (SANT’ANNA, 1989, p. 105).

Esta 'capa', este 'invólucro' era também superficial, vazio, parte de uma abstração chamada 'sociedade’. E ele tinha acabado de descobrir algo muito maior, mais profundo, mais real e valioso. Quando o bombeiro o chamara de 'louco' ocorrera uma transformação completa na autoimagem do personagem. Aquilo que ele experimentara como um sonho na verdade era seu 'eu'!

[...] o seu salvador — se podia chamá-lo assim — aplicara-lhe um rótulo novo que lhe oferecia também uma nova identidade, talvez explicando suas novas sensações, que agora ele preferia guardar para si mesmo. "É como se tudo não passasse de um sonho, inclusive eu e o bombeiro." Um sentimento, aliás, sumamente agradável, porque o libertava de certas cadeias. (SANT’ANNA, 1989, p. 103).

O faxineiro recebeu um nome novo para indicar um fenômeno novo: louco é o 'eu', loucura é a capacidade de pensar por si. Esta nova ‘jurisdição’ foi sentida como uma melhoria na vida do rapaz. Do excluído sem voz que era antes para o interno com voz própria de agora, mais uma vez, o jovem sentiu que sua vida valia a pena.

$\mathrm{Na}$ verdade, ele já se encontrava sob outra jurisdição. Não a dos dois homens de branco que chegaram para levá-lo numa ambulância, ele envergando o uniforme da Panamericana e tudo. A jurisdição sob a qual ele se encontrava era a do "outro", aquele alguém possível que soprara pensamentos em sua cabeça, sobre a marquise. E ele previa, intuitivamente, que lá no hospital deveria haver um pátio onde, flanando à vontade debaixo das árvores ou sentado num banco, ele teria todo o tempo do mundo para encontrar e conhecer o tal "outro", até que os dois se tornassem a mesma pessoa e falassem com a mesma voz. (SANT'ANNA, 1989, p. 106).

\section{Breves conclusões}

Encerra-se aqui a análise proposta do conto Um discurso sobre o método de Sérgio Sant'Anna feita a partir de uma apropriação parcial do conceito de mímesis de Aristóteles. Os objetivos foram alcançados e demonstrados através de dois níveis: a imitação de 'meios' diferentes de se representar o 'eu' (os diversos métodos) e a imitação de 'objetos’ diferentes, os dois sujeitos antagônicos entre si.

A proposta poderia se estender para outros elementos aqui não abordados. Por exemplo, poderia ser feita outra análise cujo foco fosse a imitação da moral provisória cartesiana. De fato, o faxineiro segue os mesmos preceitos que os estipulados pelo filósofo. E se não o fizemos aqui é porque a riqueza do texto literário permite múltiplos enfoques que não se esgotam. Nem aqui o pretendemos. 


\section{Referências}

ARISTÓTELES. (335 a.C.). “Arte Poética” In: A poética clássica. Introdução por Roberto de Oliveira Brandão; tradução direta do grego e do latim por Jaime Bruna. 12 ed. São Paulo: Cultrix, 2005.

CORTÁZAR, Julio. (?). Alguns aspectos do conto. São Paulo: Perspectiva, 1974. p.147-163.

DESCARTES, René. (1637). Discurso do Método. Apresentação e comentários de Denis Huisman. Trad. de Elza Moreira Marcelina. Brasília: UnB, 1985a.

. (1628). Regras para a Direção do Espírito. Lisboa: Edições 70. 1985b.

. (1641). Meditações Metafísicas. Introd. de Gilles-Gaston Granger; traduções de J. Guinsburg e Bento Prado Júnior. 4. ed. São Paulo: Nova Cultural, 1987-1988. (Coleção Os Pensadores).

GENETTE, Gerárd. (?). Discurso da narrativa. Tradução de Fernando Cabral Martins. Lisboa: Vega. 1979.

HESSEN, Johannes. (?). Teoria do Conhecimento. 7. ed. Trad. Dr. António Correia. Coimbra: Editor Arménio Amado, 1976. 206 p. (Coleção Stvdivm).

PIGLIA, R. (1999). “Teses sobre o conto” In: Formas breves. São Paulo: Companhia das Letras, 2004. p. 89-94.

POE, Edgar Allan. (1846). “A filosofia da composição” In: Poemas e ensaios. 4. ed. São Paulo: Globo, 2009. P. 113-128.

SANT'ANNA, Sérgio. (1989). “Um discurso sobre o método” In: A senhorita Simpson: histórias. São Paulo: Companhia das Letras, 1989, p. 87 - 106.

SILVA, Franklin Leopoldo e. (1993). Descartes: a metafísica da modernidade. São Paulo: Moderna, 1993. (Coleção Logos).

Artigo recebido em: 07 de julho de 2019

Artigo aceito em: 15 de julho de 2019 